\title{
HISTORICAL MINING REMAINS PRESERVED IN THE PRESENT-DAY RELIEF OF THE EUROPEAN HERCYNIAN MOUNTAINS - CASE STUDIES FROM HOLY CROSS MOUNTAINS (POLAND) AND ARDENNES (BELGIUM)
}

DOI: https://doi.org/10.18509/AGB.2021.15

UDC: 528.484:551.4]:[622.016.2:908(438:493)

\author{
Paweł Przepióra ${ }^{1}$, Tomasz Kalicki ${ }^{1}$, Ewa Nowak ${ }^{1}$, Piotr Kusztal ${ }^{2}$, \\ Geoffrey Houbrechts ${ }^{3}$, Grzegorz Pabian ${ }^{1}$, Alexandre Peeters ${ }^{3}$ \\ ${ }^{I}$ Institute of Geography and Environmental Sciences, Jan Kochanowski University in Kielce, Poland \\ ${ }^{2}$ Student Science Club of Geomorphologists ,Ztoty Bażant”, Jan Kochanowski University in Kielce, Poland \\ ${ }^{3}$ University of Liège, Unit of Physical Geography and the Quaternary Period (UGPQ), Belgium
}

corresponding author: pawelprzepiora1988@gmail.com

\begin{abstract}
The historical anthropopressure on Polish (Old Polish Industrial District) and Belgian (Ardennes) iron ore mining fields led to create very clear relief transformations. These post-mining forms have different arrangement and size. This is probably related to the geological structure, relief, period of exploitation and different technology. Also important is fact of different time of individual shafts use, as well a time of impact of denudation processes on this forms. Currently abandoned mining shafts are subject to natural processes that are constantly changing the relief. Aims of this study is to compare two selected mining fields from two diverse places in Europe, different in terms of use but also among other by geological structure. For this purpose field observations and statistical methods based on DEM were carried out. Observations and statistical analyzes showed some similarities between post-mining shafts in Belgium and Poland. This can be associated with similar iron ore mining technology in both places and probably same the time of use of these forms. The morphometry allows to recognize the probable age of these forms.
\end{abstract}

Keywords: geomorphology, historical mining, Poland, Belgium, iron ore.

\section{INTRODUCTION}

In the area of the Central Europe, there has been an intensive development of the metallurgical industry (last centuries) based on the mining and smelting of locally occurring iron ore deposits.

The mining industry developed intensively in the European medium mountains in Ardennes (Belgium) as well as the area of the Old Polish Industrial District in the Holy Cross Mountains

\section{AIM OF THE STUDY AND METHODS}

The aim of the study was to identify and explain the diversity of relief in two selected unused mining fields in European Hercinides (Fig. 1).

One of them is located in the Holy Cross Mountains (Poland), and the other one in the Ardennes (Belgium).

The historical materials and digital elevation model (DEM)[2], [3] was use to locate and measure (height, area and distance between forms) the postmining forms and make classification of of them by the artificial Kohonen neural networks method
(Poland) (Fig. 1). These areas combine a very similar way of ore mining and processing techniques, which were based on the building of many forges and blast furnaces on the small watercourses.

They were powered by a water wheel and charcoal that was obtained from nearby forests, which was produced in many charcoal hearths [1].

using Statistica and Python programs in Kohonen's 1000 algorithm, web SOFM 3-6 [4], [5].

The post-mining fields was divided in to a few sets. The method for Polish and Belgian study areas was carried out individually. Post-mining fields in Poland creates a compact complex with mining shafts of various parameters.

On this basis, 5 different sets were divided, out of which 100 post-mining forms were analyzed in total. The division was made based on the visible differences in the analyzed forms morphometry and 
their distribution within the site. In the post-mining fields in Belgium were divided 3 sets with total of 50 post-mining forms. In the case of the Belgian site, the division was based on the distribution of very similar post-mining forms arranged in 3 lines visible in the field.

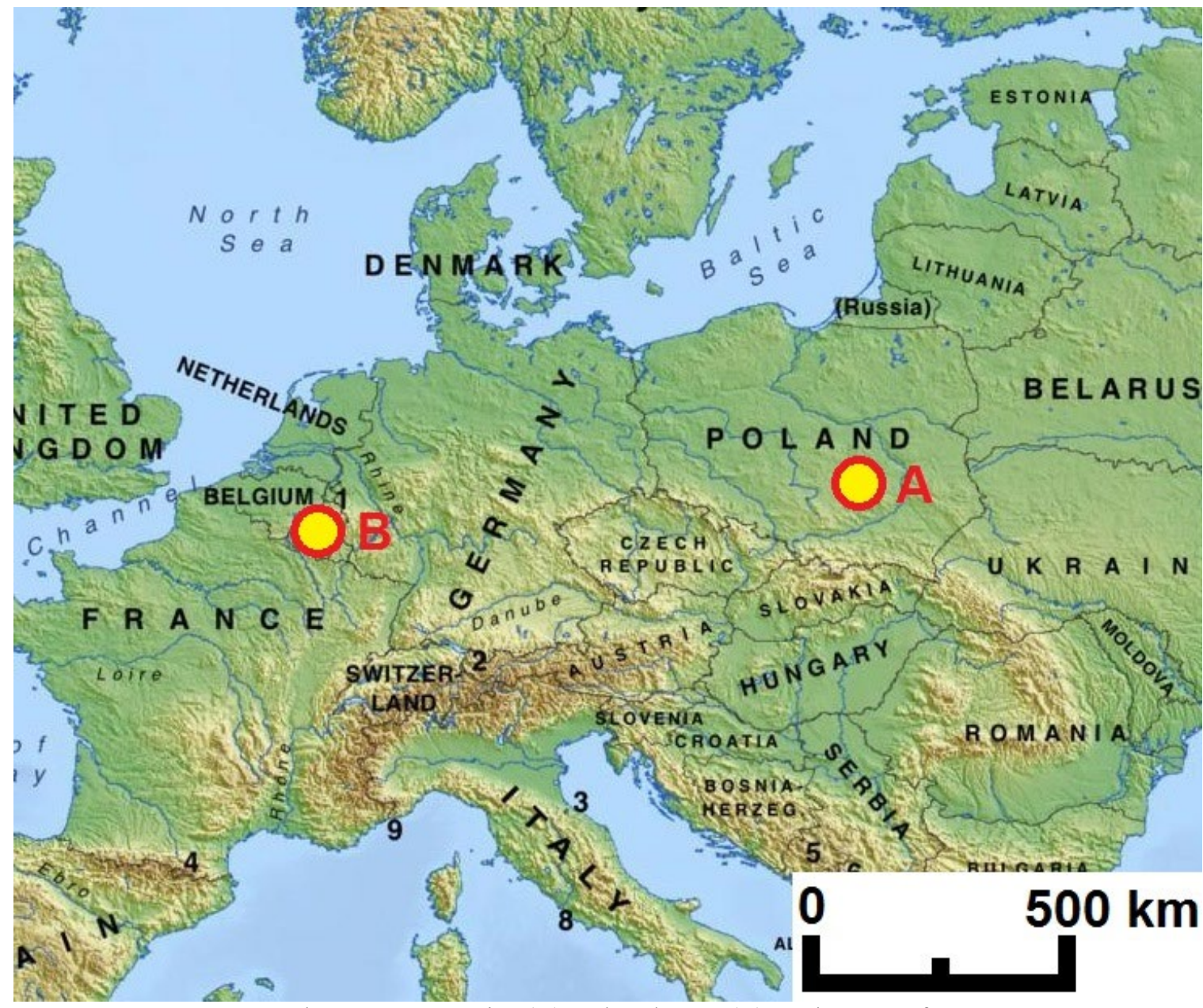

Figure 1. Holy Cross Mountains (A) and Ardennes (B) on the Map of Europe [6].
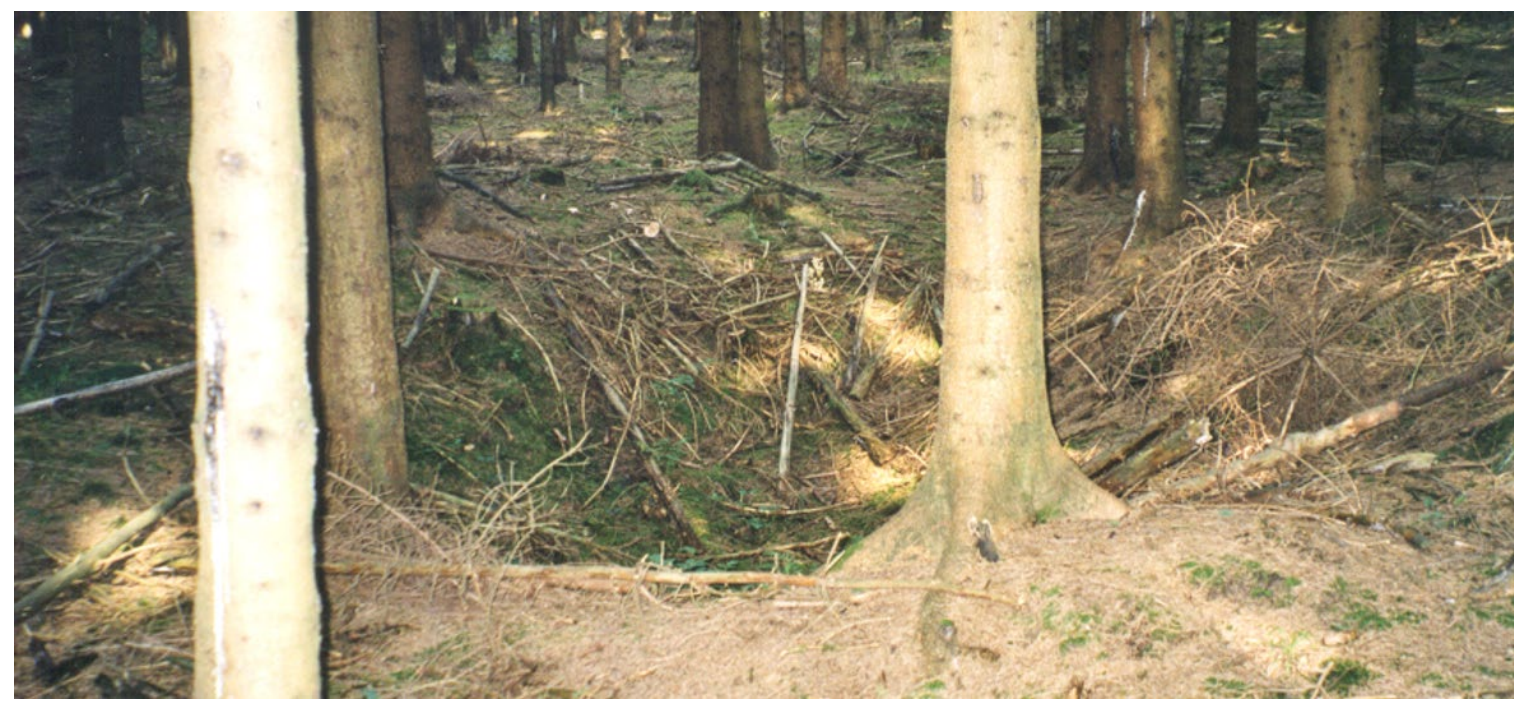

Figure 2. Excavation (shaft) in the Belgian mining field.

\section{RESULTS AND DISCUSSION}

Anthropogenic relief have been documented in mining fields, i.e. land leveling, excavation areas (mining shafts) (Fig. 2), incised road (Fig. 3A) and embankments, offsets (warps) and gangue dumps
(Fig. 3B,C), creating a specific cultural, postindustrial landscape, characterized by varied topography. 

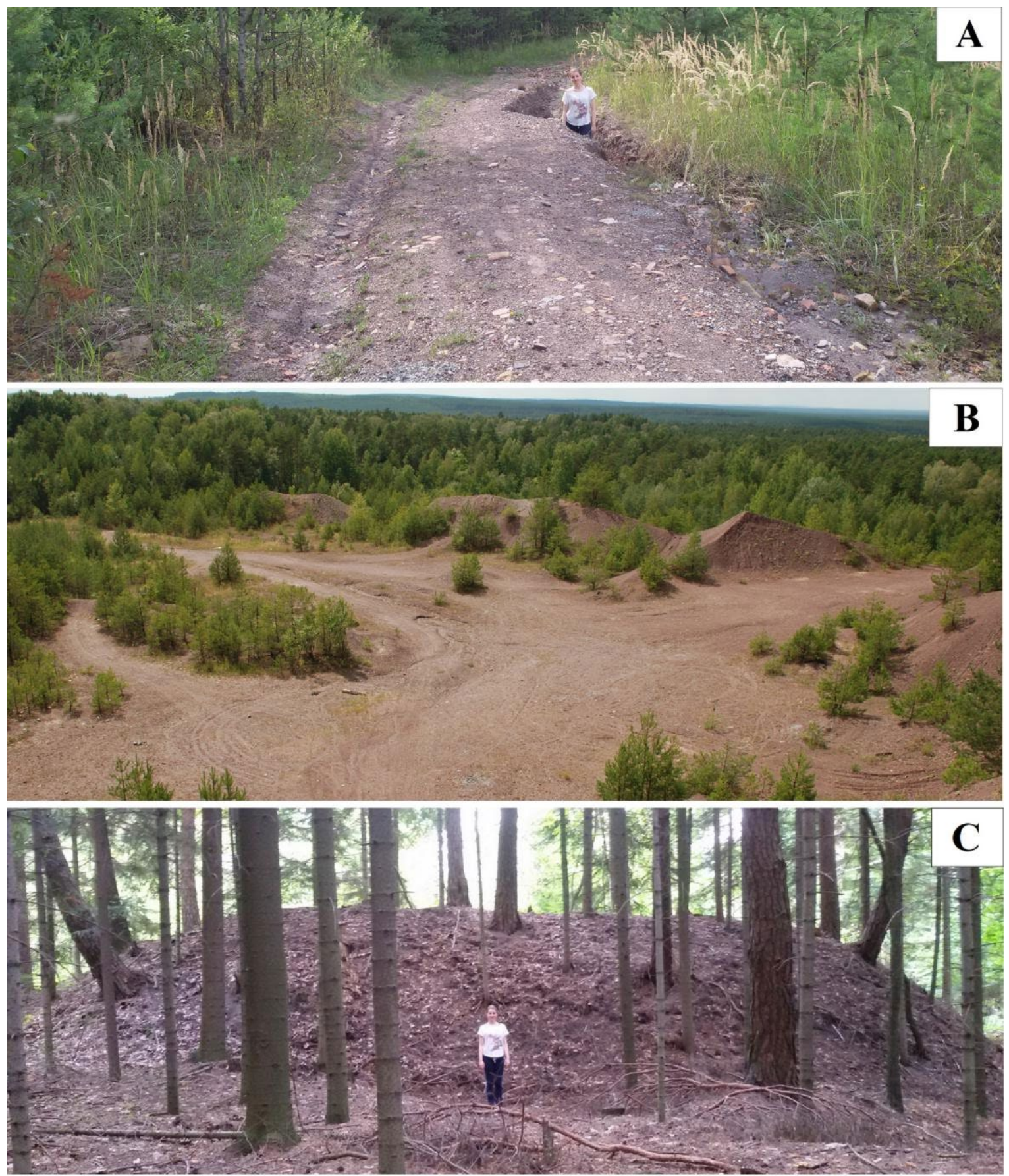

Figure 3. Anthropogenic forms in the Polish mining field. A - road made of gangue, $\mathrm{B}$ - gangue heaps on leveling of ground, $\mathrm{C}$ - gangue mound

Both research mining fields differ in the arrangement of former mining shafts and gangue mounds. In Ardennes, mining shafts are arranged in lines clearly visible on the Digital Elevation Model (DEM), when in the Holy Cross Mountains region, they form large, compact cluster (Fig. 4). The selforganizing map was made (Fig. 5), showed diversity of 100 forms in the Polish post-mining field, which results from morphometric features and distribution of anthropogenic forms [7]. 


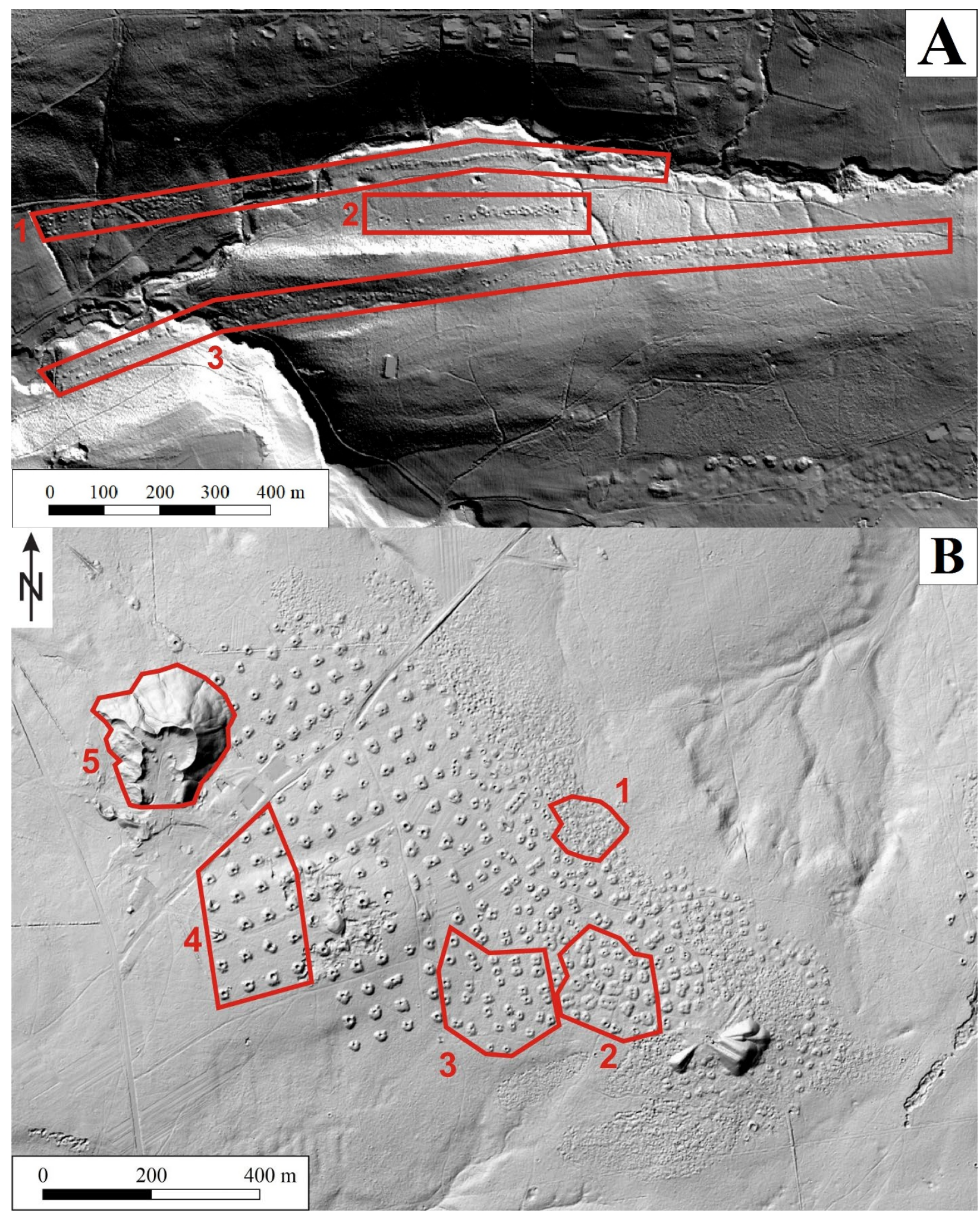

Figure 4. Digital elevation models (DEM) of studied areas of Poland [2] and Belgium [3]:

A - mining field near Hayen (south from Liège) in Belgium (1-3 - analyzed sets of forms),

B - mining field near Stąporków (north from Kielce) in central Poland (1-5 - analyzed sets of forms).

The distribution and size of anthropogenic forms occurring in the studied mining fields may be related to the geological structure, landform, stages of deposit exploitation with different mining technology, the purpose of individual shafts, the length of their use and the time of impact of denudation processes on them (Table 1) [7].
In Poland, chaotically arranged indistinct small warps (gangue mounds) can be connected with medieval mining, which consisted in mining pits digging with area about $5 \mathrm{~m} 2$ and several meters deep. To create them was used simple tools. Their former use can be show by the location on the iron ore deposits outcrop. This location was conducive 
to exploitation, especially in the Middle Ages. The raw ore was obtained off the area surface from easily accessible deposits [8]. Based on this information, it can be concluded that small mining shafts are older, and large, better preserved are younger (Fig. 4B). In the case of the Belgian site, the assumption that mining shafts visible in the topography are from the Middle Ages is confirmed by historical materials i.a. archival maps [9].

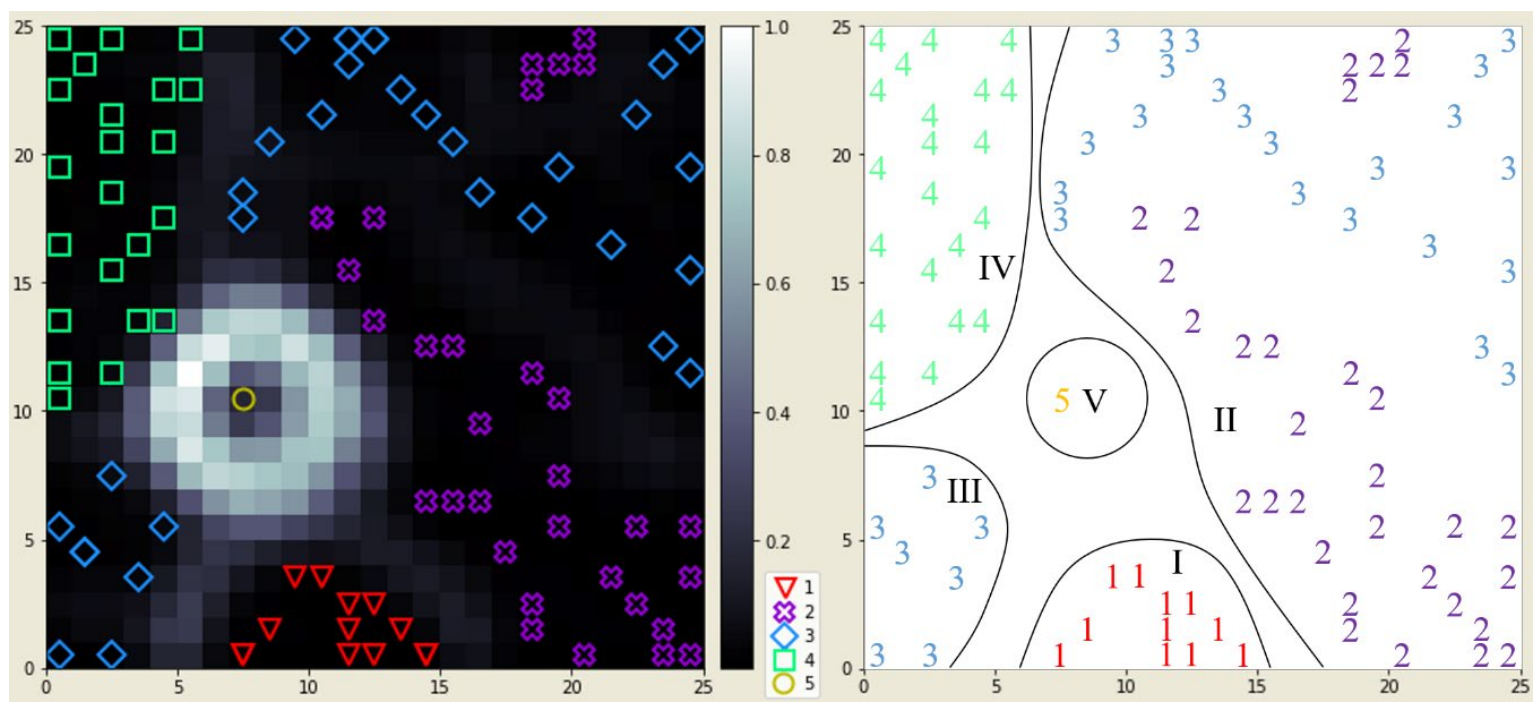

Figure 5. Classification of selected 100 anthropogenic forms of Polish mining field (Fig. 4B) by the method of Kohonen's artificial neural networks (by E. Nowak in "Statistica" and "Python")

[7] 1-5 - analyzed sets of forms, I-V - generated clusters.

Table 1. Cluster analysis by both Ward linkage method and Euclidean distance.

\begin{tabular}{|l|l|l|}
\hline \multicolumn{1}{|c|}{ Factors } & \multicolumn{1}{|c|}{ Literature } & $\begin{array}{l}\text { Relationship with placement and/or size of } \\
\text { the shafts/warps }\end{array}$ \\
\hline $\begin{array}{l}\text { Geological structure and } \\
\text { relief }\end{array}$ & {$[7],[8],[10]$} & $\begin{array}{l}\text { Outcrops of iron ore deposits favor the } \\
\text { occurrence of more excavations and warp }\end{array}$ \\
\hline $\begin{array}{l}\text { Mining technology and } \\
\text { length of shaft use }\end{array}$ & {$[7],[8],[10]$} & $\begin{array}{l}\text { Newer technology, longer exploitation - } \\
\text { deeper excavations, larger warps }\end{array}$ \\
\hline Shafts purpose & {$[7],[11]$} & $\begin{array}{l}\text { Larger warps occur at mining shafts (deeper) } \\
\text { and smaller ones at exploration (shallower) }\end{array}$ \\
\hline Denudation & {$[7]$} & $\begin{array}{l}\text { The shorter denudation impact, the more } \\
\text { excavations and warps are more visible in the } \\
\text { landscape }\end{array}$ \\
\hline
\end{tabular}

The fifty forms (shafts) selected from the Belgian post-mining field were divided into 3 sets (Fig. 4A). The one hundred forms were also selected within the Polish post-mining field. They were divided into five sets, in terms of their size, area and distribution (Fig. 4B). Then the obtained results were subjected to statistical analysis.

The results of the statistical analysis from the Belgian site showed that they are very similar in all three sets (I-VI statistical groups). Only group V is characterized by high homogeneity. It consists mainly of mining shafts from 1st set (Fig. 6A).

The post-mining field in Poland has been divided into six statistical groups (I-VI), relatively homogenic, which there are mainly forms from one set on the map. The statistical group $\mathrm{V}$ shows a great similarity between the forms of three sets that mining shafts of various sizes occur. The statistical group VI is an anomaly (post-mining heap) (Fig. 6B).

Then, all one hundred and fifty mining forms separated from both sites were statistically analyzed together. The results of the analysis showed that almost all shafts from the post-mining field in Belgium were added to groups I and II. The same statistical groups also includes shafts from the Polish site, which belong to the sets in the map where mainly small mining shafts are located. Most of the bigger shafts from the Polish site were added to statistical groups III and V. These groups are homogeneous, i.e. there are few shafts from other sets from the map including several from Belgium sets. Statistical groups IV and VI are anomalies. In group IV, post-mining heap was separated from the Polish post-mining field, while in group VI there are 3 unusual shafts from a Belgian site (Fig. 6C). 
A

Belgium 50 mining shafts divided in 6 groups

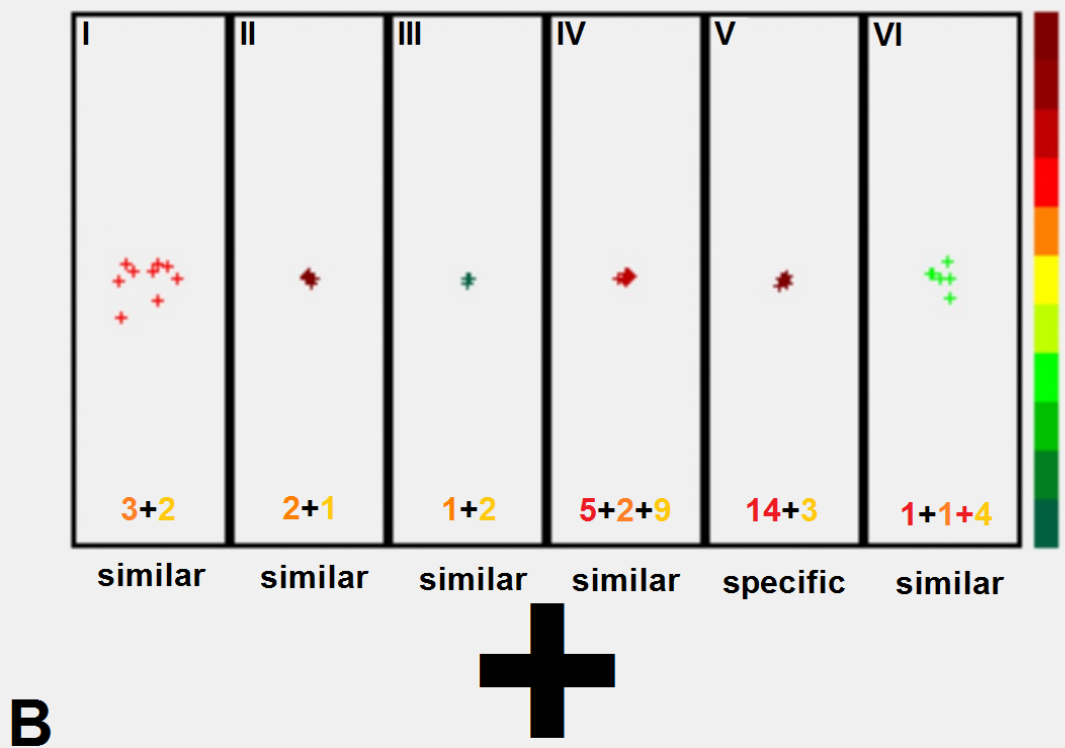

Sets nr:

$1=20$ shafts

$2=10$ shafts

$=20$ shafts

Polish 100 mining shafts divided in 6 groups

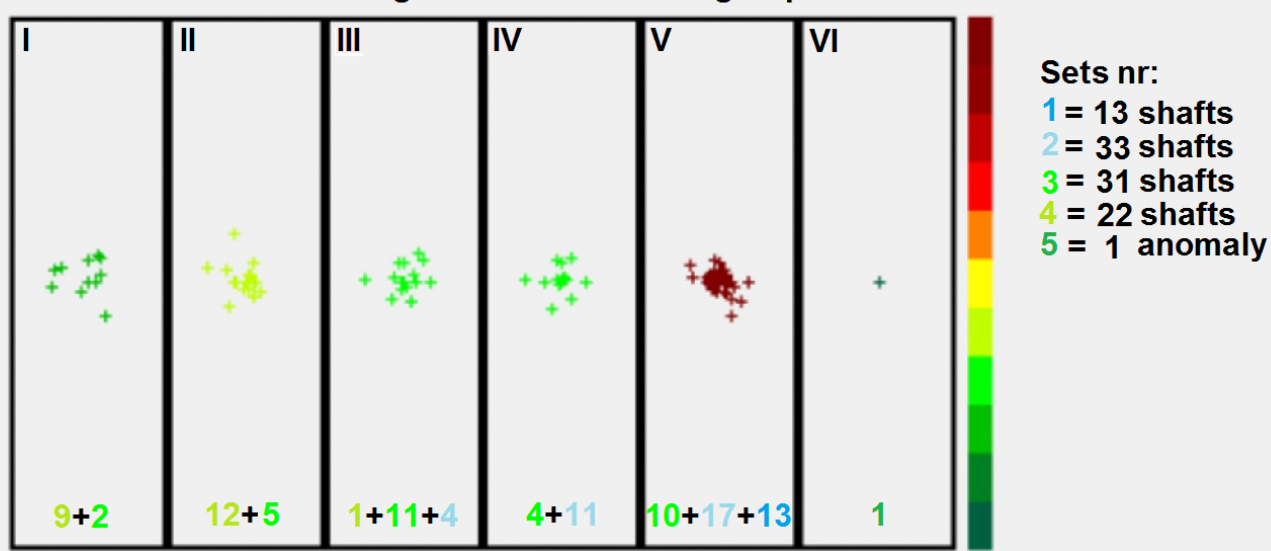

specific specific specific specific similar anomaly

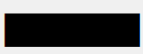

C

The sum of Polish and Belgium 150 mining shafts divided in 6 groups

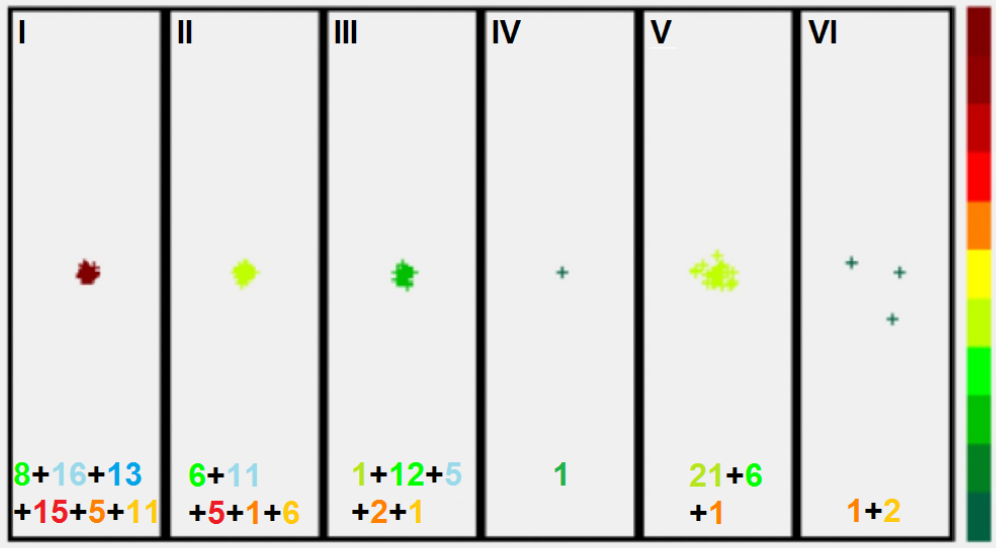

similar similar specific anomaly specific anomaly

Figure 6. Classification of selected anthropogenic forms of Belgian (A) and Polish (B) mining field and the sum of them $(C)$ by the method of Kohonen's artificial neural networks (by E. Nowak in "Statistica"). 


\section{CONCLUSIONS}

Field observations and a query of cartographic materials showed a clear differentiation in Belgian and Polish post-mining field forms. The different arrangement of them is visible. The Belgian mining shafts forming lines visible in DEM because they are situated along the contact between Devonian limestone (Givetian) and sandstone (Eifelian). The Polish post-mining fields form compact complexes. The arrangement of those forms can be connected with different type of geological structure and method of distribution of raw ore.

Visible differences in the size and arrangement of mining shafts in Osicowa Góra (Poland) may indicate iron ore mining at different periods of time. Small, many and poorly preserved mining shafts with irregular arrangement are older, while bigger and better visible are younger. The Belgian postmining field dates back to the Middle Ages, as evidenced by historical materials. The Belgian and Polish sites Comparison using statistical methods showed a great similarity of Belgian mining forms to small mining shafts from the Polish site. These results confirm that the smallest mining shafts from the Polish site also probably dug up in the Middle Ages, when metallurgy based on local iron ore deposits developed intensively in this region. The great similarity between mining shafts from Poland and Belgium can be mainly associated with the ore extraction technology, which was then available by simple methods.

\section{REFERENCES}

[1] Przepióra P., Houbrechts G., Kalicki T., Peeters A., Pabian G., Kusztal P., Nowak E. \& Rutkiewicz P. Post-mining relief and its present-day changes in the European Hercinian Mountains - cases study from Ardennes and Holy Cross Mountains, 25th Quaternary Conference, Brno, Czech Republic, pp 55, 2019.

[2] geoportal.gov.pl.

[3] geoportail.wallonie.be.

[4] Kohonen T. Self-Organizing Maps, Springer, Berlin-Heidelberg-New York, Germany-United States, 1997.

[5] Nowak E. Metody klasyfikacji w badaniach geograficznych (analiza porównawcza), Bogucki Wyd. Nauk., KielcePoznań, Poland, 2004.

[6] mapswire.com.

[7] Kusztal P., Pabian G., Kalicki T., Nowak E. \& Przepióra P. Zróżnicowanie i zmiany rzeźby terenu historycznego pola górniczego na Osicowej Górze k. Stąporkowa (NW obrzeżenie Gór Świętokrzyskich). Przegląd Geologiczny, vol. 68 , no 2, s. 127-134, 2020.

[8] Chłopek M. Dolina Czarnej: Zapomniane Dziedzictwo. Stowarzyszenie "W Dolinie Czarnej", Zabytkowy Zakład Hutniczy w Maleńcu, Maleniec, Poland, pp 1-51, 2017.

[9] Lohest M. La présente carte Tavier-Esneux à l'échelle du $1 / 25000$, succède à la feuille $n^{\circ} 147$ de la Carte géologique à $1 / 40000,1898$.

[10] Rutkiewicz P. \& Gawior D. Górnictwo kruszcowe jako czynnik kształtujący krajobraz w rezerwacie Segiet (Wyżyna Śląska) na podstawie danych lidarowych [in:] Z badań nad wpływem antropopresji na środowisko (Machowski R. \& Rzętała M.A.), UŚ, Sosnowiec, Poland, vol. 16, pp 80-86, 2015.

[11] Rutkiewicz P. Wykorzystanie danych LIDAR w badaniach zmiany rzeźby terenu, wynikających z działalności dawnych kopalń rud żelaza [in:] Z badań nad wpływem antropopresji na środowisko (Machowski R.), UŚ, Sosnowiec, Poland, vol. 18, pp 40-47, 2017. 